\title{
アレルギー性鼻炎と住環境ダニ抗原量
}

\author{
荻野 敏 ${ }^{1)} \cdot$ 榎本 雅夫 ${ }^{2)} \cdot$ 和田 光雄 ${ }^{3)}$
}

\section{Allergic Rhinitis and Levels of Dust-Mite Allergens in the Homes}

\author{
Satoshi Ogino \\ (Osaka University) \\ Tadao Enomoto \\ (Japanese Red Cross Society Wakayama Medical Center) \\ Mitsuo Wada \\ (Hitachi Chemical)
}

Several reports indicate that the severity of perennial allergic rhinitis is related to levels of dust-mite allergens. In this study, the levels of dust-mite allergens measured in the homes of 13 people with allergic rhinitis and 10 healthy volunteers. Dust specimens were collected with a vacuum cleaner and analyzed for the presence of major mite allergens (Der 1=Der p 1+Der f 1, Der 2=Der p 2+Der f 2) by using ELISA. Levels of Der 1 were higher in bedclothes, in bedrooms, and on family room floors. There were no differences between the homes of the 13 people with allergic rhinitis and the 10 healthy volunteers. No association was found between levels of dust-mite allergens and the severity of nasal symptoms. Although the levels of mite allergens increased in most of homes 2 months after cleaning, there was an insignificant tendency for improvement in nasal symptoms in homes with decreased levels 2 months after cleaning.

Key words : allergic rhinitis, dust-mite, Der 1, Der 2, nasal symptoms

\section{はじめに}

通年性アレルギー性鼻炎の原因アレルゲンとして最も 重要なものはダニである. 近年, 木造住宅から高気密化, 高断熱化住宅へと変わり，空調設備も普及し室内環境は 1 年を通してダニの好む高温多湿となり, ダニの増殖を 引き起こしている1).

通年性アレルギー性鼻炎などのアレルギー疾患の治療 の基本は原因アレルゲンの回避・除去であることから, このような家庭内でのダニの暴露からどのように回避で きるかがアレルギー疾患をコントロールしていく上で重
要である。

そこで今回, アレルギー性鼻炎患者家庭内におけるダ 二抗原量, 症状との関係, 健康人宅との比較, ダニ除去 のための環境整備との関係を調べる目的で, 家庭内での ダニの分布, ダニ抗原量を調べたところ, いくつかの興 味ある結果が得られたので若干の考察を加え報告する.

\section{対象および方法}

1. 対象

大阪大学医学部附属病院耳鼻咽喉科にて通院治療中の

1) 大阪大学保健学科

2）日本赤十字社和歌山医療センター耳鼻咽喉科

3）日立化成工業株式会社 
室内塵（HD）, ダニが原因である通年性アレルギー性鼻 炎患者のうち，家庭において掃除機にてほこりを採取す ることに同意を得た 13 患者（家庭）を対象とした. 対照 として全くアレルギー疾患を有していない教官, 学生 10 名の家庭を健康人宅として同意を取得した後, ほこりの 採取を行った。

2. 方法

室内塵採取の方法は, 各家庭の掃除機の接合部に特殊 な集塵サンプラー（日立化成工業社製）を装着し， $1 \mathrm{~m}^{2}$ あたり 2 分間掃除した後, 袋（サンプラー）を封印し日 立化成工業医薬品研究所送付した. 測定は日立化成工 業医薬品研究所に依頼し, ELISA にて行われ約 2 週間後 には各家庭, 主治医に結果が送られた. 今回の研究では, ダニ抗原量として Der p 1+Derf 1 を Der 1 量, Der p 2 $+\operatorname{Der} \mathrm{f} 2$ をDer 2 量として 2 種類の測定を行い, $\mu \mathrm{g} / \mathrm{g}$ dust で表した.

測定場所は各家庭の居間, 寝室, 寝具（ベッドあるい は敷布団)の3カ所とした。なお，4家庭においてはワン ルーム住宅のため居間と寝室が同一であった。

1 回目の採取は平成 12 年 5 月から 7 月にかけて行い, 採取後, 厚生省班会議作成の掃除メニュー2)を説明の後 配布し，それに従い掃除を施行するように依頼した．可 能であった家庭においては約 2 力月後（7〜9 月）に同じ 場所での室内塵の採取を依頼した。 なおこの際に掃除状 況のアンクートを行い, 掃除の実施状況を「全くできな
かった」「あまりできなかった」,「まあまあできた」,「ほ とんぞできた」，「全部できた」の 5 段階に分類した。

3. 統計解析

データの統計解析には, 統計ソフト SPSS を使用した. 検定には, Mann-Whitney, Wilcoxon, Kruskal-Wallis, Spearman の順位相関係数を使用し，有意水準は $5 \%$ とし た.

\section{結 果}

1. Der 1 量と Der 2 量の比較（図 1）

寝具においては Der 1 量と Der 2 量は同レベルであっ たが，居間と寝室では Der 2 がやや高い值を示したが, 有意差は認められなかった。 また Der 1 量と Der 2 量の 間にはきわめて有意な正の相関（ $\mathrm{p}<0.05 ）$ がみられた (居間 $; r=0.91$, 寝室 $; r=0.92$, 寝具 $; r=0.94$ ).

なお, 以上の結果から多くの検討では Der 1 量で比較 した.

2. アレルギー性鼻炎患者家庭と健康人宅の比較 (図 2) 両家庭とも寝具, 寝室, 居間の順に Der 1 量は高い値 を示した. 寝具では両家庭とも約 $8.1 \mu \mathrm{g} / \mathrm{g}$ dust と最も高 いレベルを示したが，居間，寝室では健康人宅の方がや や高値であったが有意差はみられなかった。

また，居間で Der 1 量が高い值であった家庭は，寝室， 寝具とも高レベルである傾向がみられ，居間と寝室，寝 室と寝具，居間と寝具の間には，いずれも有意な（ $\mathrm{p}<$

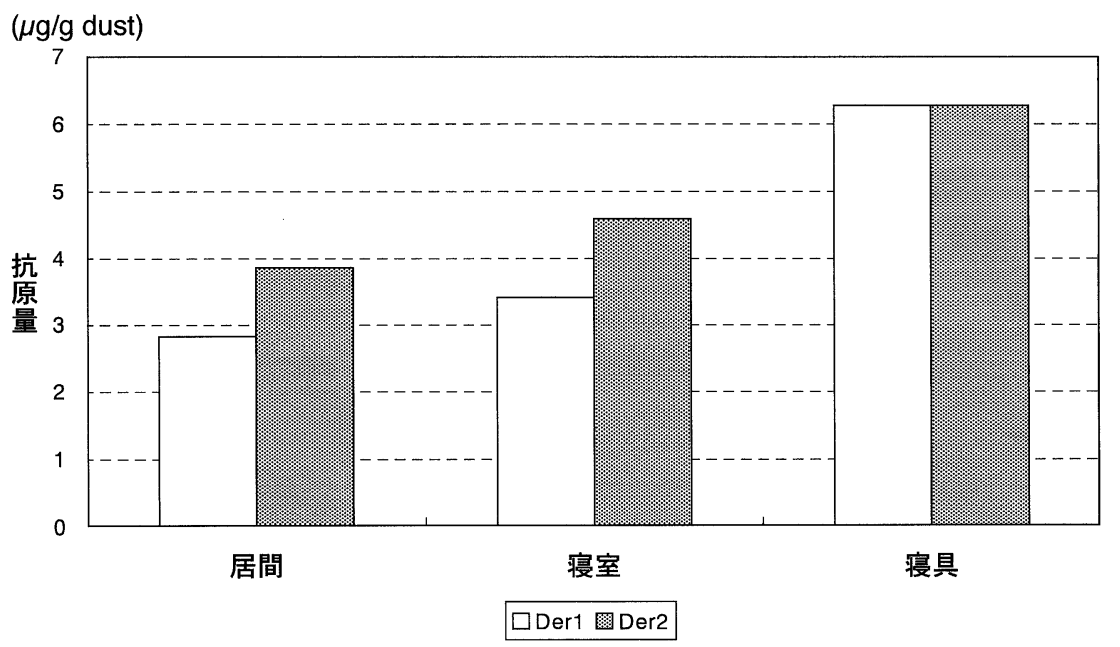

図 1 Der 1 量と Der 2 量の比較 


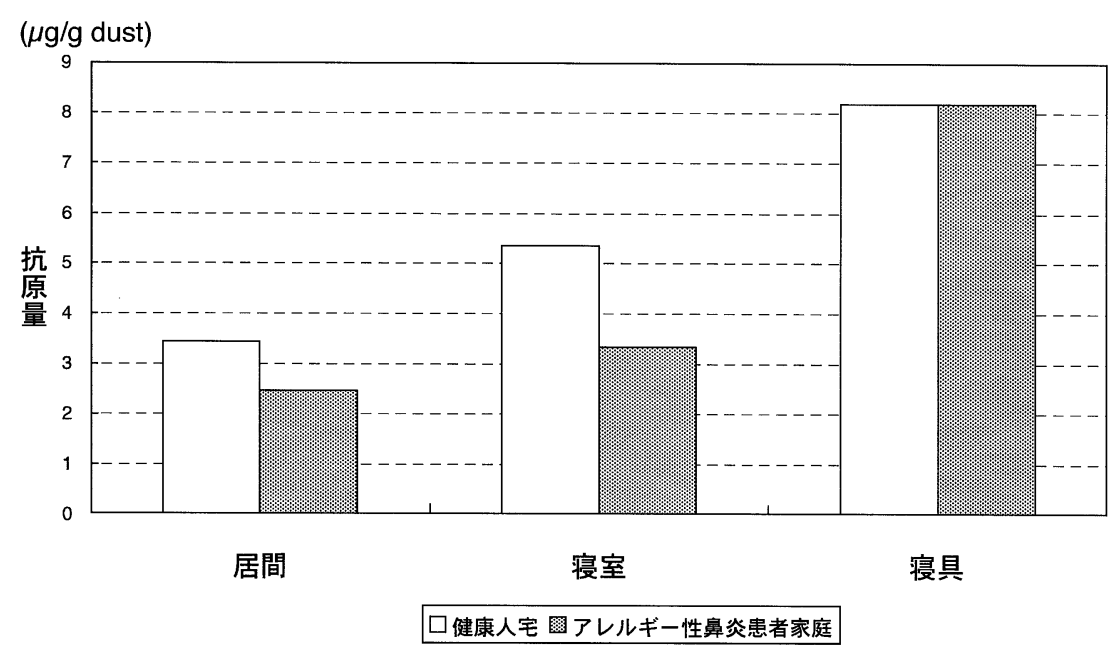

図 2 アレルギー性鼻炎患者家庭と健康人宅の比較

0.05）正の相関がみられた。

\section{3. 素材での比較}

寝室の素材での比較では, Der 1 量はカーペットで 6. $3 \mu \mathrm{g} / \mathrm{g}$ dust と最も高く, 次いでタタミ $2.7 \mu \mathrm{g} / \mathrm{g}$ dust, フ ローリング $0.7 \mu \mathrm{g} / \mathrm{g}$ dust であり, カーペットに比較しフ ローリングで有意に低レベルであった（ $\mathrm{p}<0.05)$.

居間においても同様にカーペット>タタミ>フローリ ングの順であったが有意差はみられなかった。

寝具の素材では，ベッド $9.3 \mu \mathrm{g} / \mathrm{g}$ dust，布団 $4.3 \mu \mathrm{g} / \mathrm{g}$ dust とベッドで高い值を示したが，有意差は認められな かった.
4. 掃除の実施状況（図 3)

2 回目の採取が行えたのはアレルギー性鼻炎 9 家庭, 健 康人宅 10 家庭であった。両家庭間に有意差は認められな かったが，アレルギー性鼻炎患者家庭の方が健康人宅に 比べやや実施状況は良いようであった。

5. 掃除前後の比較（健康人宅）（図 4)

Der 1 量は居間, 寝室, 寝具いずれにおいても約 2 カ月 間の掃除を行った後の 2 回目の方が高い值を示した. Der 2 量も同様の傾向を示した.

なお，アレルギー性鼻炎患者家庭においても全体とし てみると寝室でやや低下したものの, 居間, 寝具では増 加がみられた。

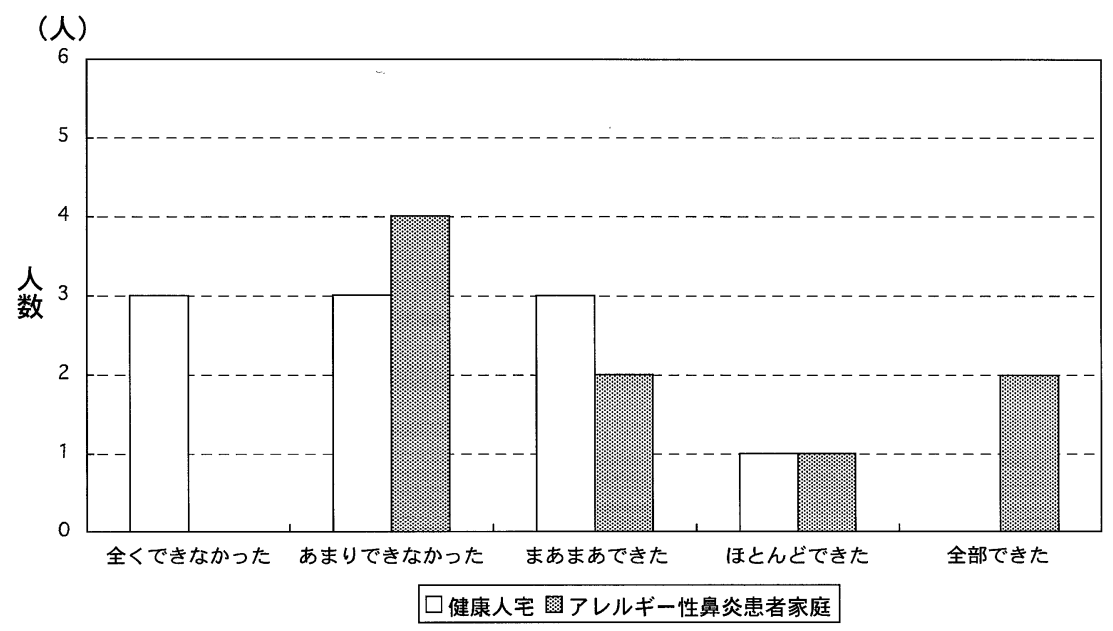

図 3 掃除の実施状況 


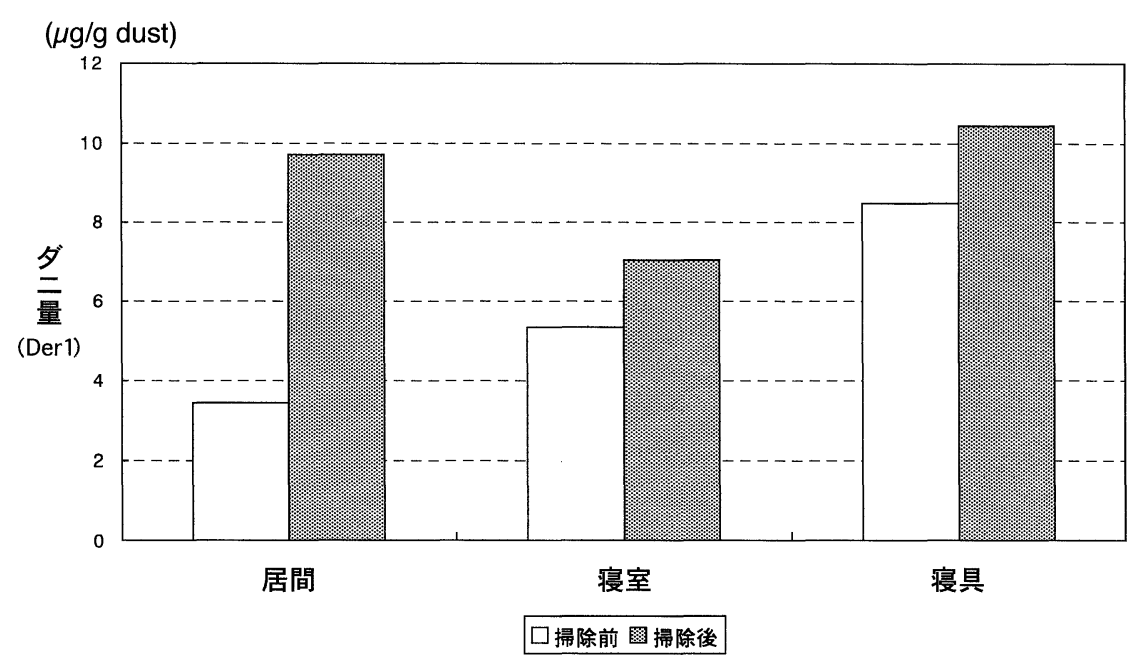

図 4 掃除前後の比較（健康人宅）

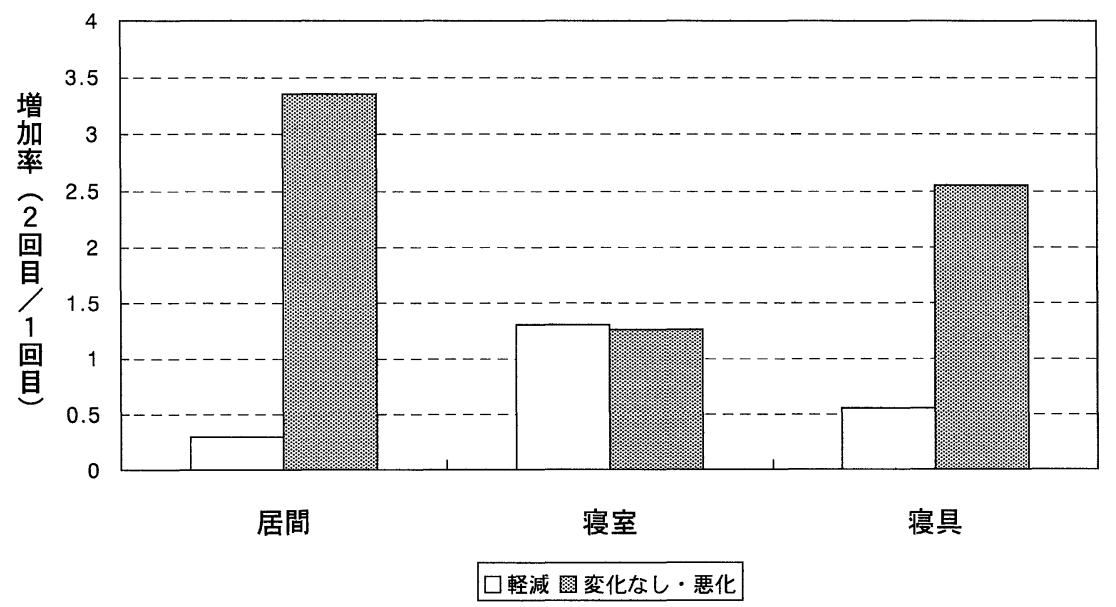

図 5 症状の変化とダニ（Der 1）量の関係（アレルギー性鼻炎患者家庭）

6. 症状の変化とダニ量の関係 (アレルギー性鼻炎患者 家庭）（図 5）

掃除前後（1 回目と 2 回目）での鼻アレルギー症状の 変化を鼻所見, 日記などから「軽減」と「変化なし・悪 化」の 2 群に分けた。「軽減」4家庭，「変化なし・悪化」 5 家庭であった. 2 回目 / 1 回目で表したが,「軽減」した 4 家庭では居間，寝具において 2 回目のほうが Der 1 量 は低下していた。 それに対し「変化なし・悪化」の家庭 では居間，寝室，寝具いずれにおいても 2 回目には増加 していた。なお，重症度，掃除状況とは明確な関連はみ られなかった。
考 察

わが国は世界でもダニの多い地域であり，ダニの種類 は世界中には約 5 万種類, 日本には約 5 千種類といわれ ている ${ }^{3)}$. 一般の家庭内の室内塵に含まれるダニは約 20 科 100 種以上に及び，そのなかでチリダニ科のヤケヒョ ウヒダニ, コナヒョウヒダニが総ダニ数の $80 \%$ 以上を占 める.この 2 種類のダニがアレルギー疾患と最も密接に 関連している(4)5).

ヒョウヒダニの抗原は数多いが, Der p 1, Derf 1 と Derp 2, Derf 2 の 2 つグループがヒョウヒダニの最も 重要なアレルゲンといわれている，グループI ア アレルゲ ン（Der p 1, Der f 1) は，ダニの粪中に多く含まれる. 
グループ II（Der p 2， Der f 2）は，ダニの虫体やその死 骸などに多く含まれる6).

ヒョウヒダニは, 高温多湿を好み温度 $25 \sim 30^{\circ} \mathrm{C}$, 湿 度 $60 \sim 80 \%$ が最も繁殖に適している. 慨は人や動物の フケ, アカ, 食べカス, カビなどで, タタミ, カーペッ 卜，布団などに潜って多数生息している ${ }^{3)}$. 近年の住宅 環境はこのような生態のダニにとって繁殖に適した環境 になってきているといえる.

ダニアレルギーの治療においてダニアレルゲン量を減 らすことが治療の基本であり, 最も重要である. ダニア

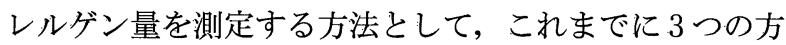
法が知られている7). (1)ダニ虫体を形態学的に識別, 同 定して計算する方法, (2)ダニ類, クモ類に共通する窒素 性の最終代謝産物であるグアニンを測定する方法, (3) ヒョウヒダニ主要アレルゲンを免疫学的に定量する方法 である。これらのなかで(3)方法でモノクローナル抗体 を用いた ELISA は, 実用性, 特異性ともに他の方法より 優れているという8)。今回はこの測定法により一定の室 内塵重量当たりのダニ量 $(\mu \mathrm{g} / \mathrm{g}$ dust $)$ で表し, ダニ量と してDer 1 量 (Derp 1+Derf1), Der 2 量 (Derp 2+Der f 2）を測定した. そして, Der 1 量がダニの污染を表す世 界共通の尺度となっていることが多いこと ${ }^{9)}$, 今回の検 討でも Der 1 量と Der 2 量はいずれの場所でも有意な正 の相関を示したことから，主に Der 1 量での検討を行っ た.

WHO の基準から，世界的に Der 1 量が $2 \mu \mathrm{g} / \mathrm{g}$ dust 以上 で感作要因, $10 \mu \mathrm{g} / \mathrm{g}$ dust 以上で症状の悪化要因となり得 るといらことから $2 \mu \mathrm{g} / \mathrm{g}$ dust 以下の低レベルにすること が環境污染対策の基準とされている6). 今回の成績では, 全体でみると $2 \mu \mathrm{g} / \mathrm{g}$ dust 以下の低レベルが大半を占めて いたが, 健康人宅の寝具では $80 \%$ 以上が $2 \mu \mathrm{g} / \mathrm{g}$ dust 以上 であり，掃除の状況とも考光合わせると，安枝8）も報告 しているように $2 \mu \mathrm{g} / \mathrm{g}$ dust のレベルは決して容易な基準 ではないといえる。

居間, 寝室, 寝具の比較では従来からの報告10) 12) と 同様，寝具が最も高く，居間が最も低レベルであった。 この傾向はアレルギー性鼻炎患者家庭と健康人宅とむに 認められた。 また素材でもカーペット>タタミ>フロー リングの順で高值を示し，寝具ではベッドが布団に比べ 高い值であった.このような報告 ${ }^{10)}$ はすでに多く認めら れ，普遍的な現象として患者の生活指導において十分に 説明すべきことといえる．また居間で Der 1 量が高い值
であった家庭は, 寝室, 寝具とも高レベルである傾向が みられ，居間と寝室，寝室と寝具，居間と寝具の間に， いずれも有意な（ $\mathrm{p}<0.05 ）$ 正の相関がみられたことか ら, 次に述べる掃除の実施は重要といえる.

掃除については各対象症例（家庭）に対して十分に説 明をしたつもりであったが，アレルギー性鼻炎患者家庭 の方が健康人宅に比べやや実施状況は良いようであった とはいえ，「全部できた」と答えたのはアレルギー性鼻炎 の 2 家庭だけであった。 それとも関連し 1 回目と 2 回目 の比較では居間, 寝室, 寝具いずれにおいても 2 回目の 方が高い值を示した. 今回の検討は 1 回目の採取は $5 \sim$ 7 月, 2 回目は約 2 力月後 $(7 \sim 9$ 月) に行っている.こ の期間はダニの繁殖に最も適している時期3)であったた め掃除の影響が現れなかったことも考えられるが，確実 にダニ量を減らすためには徹底した掃除メニューの実施 が必要といえる.

ダニ量と症状の関係は榎本ら 13)14) は重症例の家庭ほど ダニ量が多く, 症状とアレルゲン量は相関すると述べて いる. 中山ら 15) もアトピー性皮膚炎家庭でも同様の関係 がみられるとしている. しかしダニ量と症状には相関が ないといら報告1617) もかなりみられる. 今回の検討では 症状の重症度とダニ量には明確な関連はみられなかっ た。しかし症例が少なく断定はできないが，症状が「軽 減」した家庭では「変化なし・悪化」の家庭に比べ 2 回 目のダニ量は 1 回目より低下している傾向がみられた。 ダニ量と症状の関係をみるためには単位面積当たりのダ ス卜量, ダニ数も考慮したさらに多くの研究が必要と思 われるが，少なくともダニが原因であるアレルギー疾患 家庭においてはダニの除去を行うことはきわめて重要な 対策といえる。

今回の成績から明確な結論を出すには症例も少なく不 十分ではあるが，ダニがアレルギー疾患，症状に関与し ていることは確かであり, ダニアレルゲンの回避はアレ ルギー疾患をコントロールしていく上で重要であり, 環 境污染対策を患者に十分指導した上で，治療に当たって いくことがわれわれの使命といえよう。

\section{まとめ}

1）ダニが原因の通年性アレルギー性鼻炎患者 13 家庭 と健康人宅 10 家庭を対象に, ダ二量, 症状との関係, 環 境整備としての掃除の影響などを検討した。

2）測定は，日立化成工業社製集塵サンプラーにより室 
内塵採取, 処理後, ELISA にて行われダニ抗原量は Der 1 および Der 2 量として測定され， $\mu \mathrm{g} / \mathrm{g}$ dust で示された.

3）アレルギー性鼻炎患者家庭，健康人宅ともダニ量 （Der 1 量）は寝具で最も高く, 次いで寝室, 居間の順で あった。

4）素材ではフローリングと比較し，カーペットで有意 に高いダニ量を示した.

5)アレルギー症状の程度とダニ量の間には明確な関連 はみられなかった。

6）２回目の採取が行われた通年性アレルギー性鼻炎 9 家庭では, 症状が「軽減」した家庭では「変化なし・悪 化」の家庭に比べ 2 回目のダニ量は 1 回目より低下して いる傾向がみられた。

7）確実にダ二量を減らすためには徹底した掃除メ ニューの実施が必要であり，それに加え，寝室や寝具を ダニの繁殖しにくい素材に変えたり，防ダニ製品を使用 するなど，より厳密な環境整備を指導して行くことが重 要であると思われた。

稿を終えるにあたり，研究の遂行，データの採取，文献の収 集等に多大なご尽力を頂いた大阪大学医学部保健学科立石玉樹 様に深謝致します．またご指導頂きました長野皮膚科医院長野 拓三先生，ダニ抗原量測定にご協力頂いた日立化成工業医薬品 研究所の皆様に感謝致します。

なお，本論文の要旨は第 63 回耳鼻咽喉科臨床学会 $(2001$ 年 6 月，沖縄）で口演した。

\section{参考文献}

1）鳥居新平 : わが国の住居環境におけるアレルギー問題の概 要. J Natl Inst Public Health $47: 2 \sim 6 ， 1998$.

2）佐々木聖：奨励できる掃除メニューの一例．厚生省アレル ギー総合研究「住宅班」報告書. 22 ～ 23 頁， 1995 .

3）福田英三：ダニ対策. からだの科学 $186: 70 \sim 72 ， 1996$.

4) Voorhorst R, Spieksma FTM, Varekamp H, et al. : The housedust mite (Dermatophagoides pteronyssinus) and the aller- gens it produces; identity with the house-dust allergen. J Allergy $39: 325 \sim 339,1967$.

5) Miyamoto $\mathrm{T}$, Oshima $\mathrm{S}$, Ishizaki $\mathrm{T}$, et al. : Allergenic identity between the common floor mite (Dermatophagoides farinae Hughes, 1961) and house dust as a causative antigen in bronchial asthma. J Allergy $42: 14 \sim 28,1968$.

6）安枝 浩：気管支喘息におけるダニアレルゲン. 医学のあ ゆみ $159: 557$ ～560， 1991.

7) Platts-Mills TAE and de Weck $\mathrm{T}:$ Dust mite allergens and asthma. J Allergy Clin Immunol $83: 416 \sim 427,1989$.

8）安枝 浩：室内環境中のダニアレルグン量の測定とその応 用.アレルギー $49: 388 \sim 390 ， 2000$.

9）阿南貞雄：アレルゲン対策. 小児科診療 $63: 59 \sim 64,2000$.

10）西岡謙二：ダ二抗原量と喘息発症. 現代医療 31 (増 II）: $1319 \sim 1323,1999$.

11）坂口雅弘：環境アレルゲンの定量 一ダニアレルゲンを中心 に一.アレルギーの臨床 $17: 494 \sim 498,1997$.

12）佐々木聖：チリダニ抗原除去 一アレルギー対策一. 小児科 $38: 149 \sim 159,1997$.

13）榎本雅夫, 崁 良博：アレルギー性鼻炎と環境整備. アレ ルギー科 $7: 505 \sim 509,1999$.

14）榎本雅夫, 猋 良博, 芝 埜彰: アレルギー性鼻炎に対す る抗原の除去・回避. 現代医療 31 (増 VI)：59〜 64, 1999.

15）中山秀夫, 久米井晃子：ダニ除去による治療. 皮膚臨床 40 ： $980 \sim 983$, 1998.

16) Ross MA, Curtis L, Scheff PA, et al. : Association of asthma symptoms and severity with indoor bioaerosols. Allergy 55 : $705 \sim 711,2000$

17) Huss K, Adkinson NF Jr, Eggleston PA, et al. : House dust mite and cockroach exposure are strong risk factors for positive allergy skin test responses in the Childhood Asthma Management Program. J Allergy Clin Immunol $107: 48 \sim 54$, 2001.

原稿受付 : 平成 13 年 8 月 9 日

原稿採択：平成13年 9 月 5 日

別刷請求先 : 荻野 敏

于565-0871 吹田市山田丘1-7

大阪大学医学部保健学科 